\title{
Age distribution of COVID-19: a key in developing prophylactic medicine for serious lower respiratory tract involvement of coronavirus infection
}

\author{
Mehrdad Jalalian $^{1}$, Alireza Bolourian ${ }^{2}$
}

${ }^{1}$ Editor-in-Chief, Electronic Physician Journal, Mashhad, Iran

${ }^{2}$ Pharmacy School, Oregon State University, Corvallis, Oregon, USA

Type of article: Editorial

\begin{abstract}
This short editorial suggests that the ACE2 receptor could be the focus of prophylactic and curative medicine for pulmonary involvement of coronavirus infection. The editorial also proposes hypotheses to examine by clinical researchers.

Keywords: COVID-19, Prophylaxis, Coronavirus, ACE2, S-protein, Estrogen, Testosterone
\end{abstract}

\section{Abbreviations / Acronyms:}

ACE2: Angiotensin-converting Enzyme 2, COVID-19: Coronavirus Disease 2019

\section{Editorial:}

Coronavirus disease 2019 (COVID-19) is the ongoing pandemic infection with coronaviruses, which initially reported in Wuhan, China. The situation is getting worse while the specific medicine or vaccine yet to come. A main feature of the infection is that children carry the virus very frequently; but the pulmonary involvement is rare in childhood (1-3). From the pathogenesis point of view, we know that the membrane ACE2 plays the main role in binding the coronavirus to its S-protein (4). Based on the facts that (i) estrogen and testosterone are the upregulators of ACE2 gene expression (5), and (ii) the sex hormones are absent in childhood, we propose two hypotheses that might be valuable for finding an efficient prophylactic agent in protecting the infected patients from development of serious lower respiratory tract involvement: 1) the sex hormones are the key reason of the almost 0 and 1 (binary) age distribution model of pulmonary involvement among children and adults; 2) Suppressing the ACE2 expression in epithelial cells of lung may limit the COVID-19 infection to a mild upper respiratory infection by preventing the pulmonary involvement. Such medicine can be administered by a systemic rout or preferably deep inhalation that specifically targets pulmonary epithelial cells. Since the development of such prophylactic medicine may protect medical staffs and other individuals who are in close contact with patients, we highly recommend examining the hypotheses at the earliest time.

\section{Conflict of Interest:}

There is no conflict of interest to be declared.

\section{Authors' contributions:}

Both authors contributed to this project and article equally. Both authors read and approved the final manuscript.

\section{References:}

1) Liu W, Zhang Q, Chen J, Xiang R, Song H, Shu S. Detection of Covid-19 in Children in Early January 2020 in Wuhan, China. N Engl J Med. 2020 Mar 12. PMID: 32163697 DOI: 10.1056/NEJMc2003717. [Epub ahead of print]

2) Wu Z1, McGoogan JM1.Characteristics of and Important Lessons From the Coronavirus Disease 2019 (COVID-19) Outbreak in China: Summary of a Report of 72314 Cases From the Chinese Center for

\section{Corresponding author:}

Dr. Mehrdad Jalalian. Editor-in-Chief, Electronic Physician Journal, Mashhad, Iran.

Tel: +98.9164337176, E-mail: mehrdad.medic@gmail.com

Received: February 16, 2020, Accepted: March 03, 2020, Published: March 2020

(C) 2020 The Authors. This is an open access article under the terms of the Creative Commons Attribution-NonCommercialNoDerivs License, which permits use and distribution in any medium, provided the original work is properly cited, the use is non-commercial and no modifications or adaptations are made. 
Disease Control and Prevention. JAMA. 2020 Feb 24. DOI: 10.1001/jama.2020.2648. PMID: 32091533. [Epub ahead of print]

3) Cai J, Xu J, Lin D, Yang Z, Xu L, Qu Z, Zhang Y et al. A Case Series of children with 2019 novel coronavirus infection: clinical and epidemiological features. A Case Series of children with 2019 novel coronavirus infection: clinical and epidemiological features. Clin Infect Dis. 2020 Feb 28. DOI: 10.1093/cid/ciaa198. PMID: 32112072

4) Hussin A.RothanaSiddappa N.Byrareddy. The epidemiology and pathogenesis of coronavirus disease (COVID-19) outbreak. Journal of Autoimmunity. Available online 26 February 2020. DOI: 10.1016/j.jaut.2020.102433, In Press

5) Bukowska A, Spiller L, Wolke C, Lendeckel U, Weinert S, Hoffmann J et al. Protective regulation of the ACE2/ACE gene expression by estrogen in human atrial tissue from elderly men. Exp Biol Med (Maywood). 2017 Aug; 242(14):1412-1423. DOI: 10.1177/1535370217718808, PMID: 28661206 PMCID: PMC5544171. Epub 2017 Jun 29. 